\title{
Pengaruh Kinerja Keuangan terhadap Return saham perusahaan Mining and Mining Services terdaftar di Bursa Efek Indonesia Periode 2012-2016
}

\author{
Hilwa Anggraini \\ Universitas Sjakhyakirti \\ Email: hilwaanggraini196@yahoo.com \\ Riri Hanifa \\ Universitas Sjakhyakirti \\ Email: ririhanifa0718@gmail.com \\ Patmawati \\ Universitas Sriwijaya \\ Email:patmawati@feunsri.ac.id \\ Irsan \\ Universitas Sjakhyakirti \\ Email:Irsan@unisti.ac.id
}

\begin{abstract}
This study aims to analyze the effect of financial performance on stock returns in mining and mining service companies in the Indonesia Stock Exchange for the period 2012-2016. The research method used is quantitative descriptive. The analysis techniques used in this study are the Classic Assumption Test, Multiple Regression Analysis, t Test and F Test. The sampling technique is purposive sampling. The independent variable used in this study is financial performance. Financial performance intended here is financial performance measured using financial ratios, namely Debt to Equity Ratio (DER), Earning per Share (EPS), Return on Asset (ROA), Net Profit Margin (NPM) and Price Earning Ratio (PER), while the dependent variable is Stock Return. The sample in this study was 20 mining and mining services companies on the Indonesia Stock Exchange in the 2012-2016 study period. Analysis of the data used in this study is multiple linear regression ( $\mathrm{t}$ test and $\mathrm{f}$ test) obtained with SPSS. The results showed that the DER, NPM and PER variables did not affect stock returns and only EPS and ROA variables affected stock return.
\end{abstract}

Keywords: Return Saham, ROA, DER, EPS, NPM, dan PER

\begin{abstract}
Abstrak
Penelitian ini bertujuan untuk menganalisa pengaruh kinerja keuangan terhadap return saham pada perusahaan mining and mining service di Bursa Efek Indonesia periode 2012-2016. Metode Penelitian yang dipergunakan adalah Deskrisptif Kuantitatif. Teknik Analisis yang dipergunakan dalam penelitian ini adalah Uji Asumsi Klasik, Analisis Regresi Berganda, Uji t dan Uji F. Teknik pengambilan sampel adalah Purpossive sampling. Variabel Independen yang digunakan dalam penelitian ini adalah kinerja keuanga.. Kinerja keuangan yang dimaksudkan disini adalah kinerja keuangan yang diukur dengan menggunakan rasio keuangan yaitu variabel Debt to Equity Ratio (DER), Earning per Share (EPS), Return On Asset (ROA), Net Profit Margin (NPM) dan Price Earning Ratio (PER), sedangkan variabel dependen adalah Return Saham. Sampel dalam penelitian ini adalah 20 perusahaan mining and mining services di Bursa Efek indonesia pada periode penelitian 2012-2016. Analisis data yang digunakan dalam penelitian ini adalah regresi Linear Berganda (Uji t dan Uji f) yang diperoleh dengan SPSS. Dari hasil penelitian menunjukkan bahwa variabel DER,NPM dan PER tidak berpengaruh terhadap return saham dan hanya variabel EPS dan ROA yang berpengaruh terhadap return saham.
\end{abstract}

Kata kunci: Return Saham, ROA, DER, EPS, NPM, dan PER 


\section{Pendahuluan}

Perkembangan pasar modal yang dikaitkan dengan pengaruh global dan krisis ekonomi yang sempat melanda pada tahun 2008 akibat dari subprime mortgage di Amerika Serikat, telah memberikan tantangan yang sangat besar bagi perusahaan-perusahaan go public untuk berangsur-angsur pulih, tetapi perkembangan pasar modal belumlah semaksimal mungkin seperti sebelumnya. Dalam menjalankan fungsi ekonominya, pasar modal menyediakan fasilitas memindahkan dana dari lenders ke borrowers, dengan menginvestasikan kelebihan dana yang mereka miliki, lenders berharap kan menerima imbalan atas penyerahan dana tersebut bagi borrowers dengan tersedianya dana tersebut memungkinkan mereka melakukan investasi tanpa harus menunggu dari hasil operasi perusahaan.

Return saham adalah pengembalian saham beserta hasilnya dari pihak broker atau perusahaan kepada investor yang telah melakukan investasi pada perusahaan tersebut. Bisa saja return saham dilakukan karena telah habis masa kontrak kerja sama dan tidak dilakukan perpanjangan atau masalah lainnya seperti likuidasi perusahaan. Dalam dunia pasar saham, seorang investor yang melakukan investasi dengan membeli saham tentu telah yakin betul dengan segala risiko dan segala ketidak pastian yang akan didapatkan di masa yang akan datang. Hasil return saham bisa berupa keuntungan (capital gain) atau kerugian (capital loss), sebab dalam bisnis investasi saham seorang investor selalu dihadapkan pada risiko yang tidak terduga (belajar investasi.my.id)

Alasan dilakukannya penelitian terhadap perusahaan pertambangan batubara dimana saham-saham pertambangan batubara adalah saham-saham yang lebih berisiko daripada saham-saham lainnya. Fluktuasi harga saham ini amat tinggi yang dapat turun dan naik dengan cepat. Fluktuasi yang drastis ini tentu saja dapat mempengaruhi harga jual saham. Selain itu alasan memilih sektor pertambangan adalah karena menurunnya harga minyak dunia setahun belakangan ini sehingga menurunkan harga batubara sebagai bahan bakar subtitusi secara signifikan, selain itu industri pertambangan sangat memerlukan modal yang sangat besar misalnya alat berat, alat transportasi dan padat risiko jika dalam eksplorasi tersebut tidak menemukan bahan galian yang memiliki keuntungan untuk ditambang maka pemilik industri tersebut harus menerima kerugian awal yang cukup besar, risiko pasar yang berhubungan dengan perubahan harga dan risiko kebijakan pemerintah yang berhubungan dengan peruabahan pajak dan harga domestik.

Harga batubara yang mengalami penurunan pada tahun 2014 menjadi salah satu faktor negatif bagi kinerja emiten sektor pertambangan seiring dengan permintaan dari tiongkok dan India yang mengalami penurunan. Sementara pasokan batubara dari Indonesia dan sejumlah negara komoditas mengalami peningkatan. Hal ini berakibat terjadinnya korban pemutusan hubungan kerja yang telah mencapai 11.471 orang menurut data hingga akhit tahun 2015 yang tercatat di dinas tenaga kerja Kalimantan Timur (Tempo.co). Penelitian yang dilakukan oleh Rendra Yuli Aditya (2014) mengetahui pengaruh kinerja keuangan yang diproksi melalui return on assets, earnings per shares, price earnings ratio terhadap harga saham Perusahaan rokok yang terdaftar di BEI mengatakan bahwa ROA, EPS dan PER mempunyai pengaruh yang signifikan terhadap Return Saham. Zuliarni (2012) yang melakukan penelitian berkenaan dengan Pengaruh Kinerja Keuangan Terhadap Harga 
Saham Pada Perusahaan Mining And Mining Service Di Bursa Efek Indonesia (BEI), menemukan bahwa ROA dan PER yang berpengaruh signifikan positif terhadap harga saham, sedangkan DPR tidak berpengaruh signifikan terhadap harga saham. Penelitian yang dilakukan oleh Made Dimas (2014) mengatakan bahwa bahwa variabel Return On Asset (ROA) berpengaruh positif dan signifikan terhadap Harga Saham Perbankan. Penelitian Wahid (2014) menghasilkkan bahwa Debt to Equity Ratio (DER) tidak berpengaruh terhadap return saham, Return on Assets (ROA) berpengaruh terhadap return saham, dan Earning per Share (EPS) tidak berpengaruh terhadap return saham. Berdasarkan fenomen dan research gap tersebut diatas penulis berminat untuk melakukan penelitan untuk mengetahui dan menganalisis "Pengaruh Kinerja Keuangan terhadap Return saham perusahaan Mining and Mining Services terdaftar di Bursa Efek Indonesia Periode 2012-2016".

\section{Literature Review}

2.1 Kinerja Keuangan

Saham merupakan bagian dari salah satu efek yang diperjual belikan atau diperdagangkan di pasar modal. Suatu perusahaan dapat menjual hak kepemilikannya dalam bentuk saham (stock). Pengertian saham mempunyai definisi yang beragam terdapat berbagai sumber yang menyatakan definisi tentang saham diantaranya menurut Sartono (2005) saham adalah suatu jenis surat berharga jangka panjang untuk memenuhi kebutuhan jangka panjang. Saham adalah surat bukti atau tanda kepemilikan bagian modal suatu perseroan terbatas (Siamat,2006). Dalam transaksi jual beli dibursa efek, saham merupakan instrument yang dominan diperdagangkan. Setiap perusahaan yang akan menjual saham kepada para investor mempunyai tujuan yang berbeda-beda. Pada umumnya tujuan perusahaan adalah untuk memperbaiki struktur modal, meningkatkankapasitas produksi, memperluas pemasaran, memperluas hubungan bisnis, dan meningkatkan kualitas menejemen. Saham dapat dibagi ke dalam dua kelompok menurut Riyanto (2005): 1) Saham Biasa (common stock), adalah saham yang mewakili jumlah kepemilikan dalam suatu perusahaan. Jika perusahaan misalnya memiliki 100 lembar saham dan seseorang memiliki satu perseratus dari perusahaan tersebut, dan 2) Saham Preferen (preferred stock) adalah saham yang memberikan hak untuk mendapatkan deviden dahulu dari saham biasa, disamping itu mempunyai preferensi untuk mengajukan usul pencalonan direksi atau komisaris.

\subsection{Penilaian Saham}

Saham Menurut Tandelilin (2005) dalam penilaian saham dikenal adanya tiga jenis nilai, yaitu: nilai buku, nilai pasar, nilai intrinsik saham. Nilai buku merupakan nilai yang dihitung berdasarkan pembukuaan peruasahaan penerbit saham (emiten). Nilai pasar adalah nilai saham di pasar, yang ditunjukkan oleh harga saham tersebut dipasar. Sedangkan nilai intrinsic atau dikenal sebagai nilai teoritis adalah nilai saham yang sebenarnya atau seharusnya terjadi. Investor berkepentingan untuk mengetahui ketiga nilai tersebut sebagai informasi penting dalam pengambilan keputusan investasi yang tepat. Dalam membeli atau menjual saham, investor akan membandingkan nilai intrinsic dengan nilai pasar saham bersangkutan. Jika nilai pasar suatu saham lebih tinggi dari nilai intrinsiknya, berarti saham tersebut tergolong mahal (overvalue). Dalam situasi seperti ini investor tersebut bisa mengambil keputusan untuk menjual saham tersebut. Sebaliknya 
jika nilai pasar saham dibawah nilai intrinsiknya, berarti saham tersebut tergolong murah (undervalue), sehingga dalam situasi seperti ini investor sebaiknya membeli saham tersebut.

\subsection{Harga Pasar Saham}

Harga pasar saham merupakan harga yang ada dipasar sekunder dimana pada pasar tersebut terjadi tawar menawar harga atas suatu efek yang diperjual belikan di bursa efek. Sedangkan berdasarkan kamus pasar modal memberikan definisi khusus untuk harga pasar saham yaitu nilai pasar sekuritas yang ditentukan berdasarkan kurs resmi terakhir (IAI,2005). Dapat dikatakan bahwa harga pasar saham tergantung pada kekuatan permintaan dan penawaran saham di pasar modal sesuai dengan motif perilaku yang dimiliki investor. Dalam pasar modal yang efisien semua sekuritas diperjual belikan pada harga pasar. Harga pasar saham akan selalu berfluktuasi dari hari ke hari dan hal ini akan berlangsung selama saham tersebut masih listing atau terdaftar di pasar sekunder. Jika perusahaan yang mengeluarkan saham (emiten) telah go public, maka pemilik perusahaan adalah masyarakat luas yang memiliki saham perusahaan tersebut. Tujuan memiliki saham suatu perusahaan antara lain adalah ingin memperoleh dividen, deviden akan diberikan oleh emiten apabila perusahaan tersebut akan memperoleh laba ( laba dalam hal ini adalah laba setelah pajak) dan sebagian dibagikan sebagai deviden kepada para pemegang saham dan sebagaian lagi ditahan oleh perusahaan (disebut laba ditahan). Apabila laba yang diperoleh kecil, maka deviden yang akan dibagikan juga kecil. Oleh karena itu agar para pemegang saham dapat menikmati deviden yang besar, maka manajemen perusahaan juga akan berusaha untuk memperoleh laba yang sebesarbesarnya guna meningkatkan kemampuan membayar deviden. Tinggi rendahnya harga saham banyak dipengaruhi oleh kondisi emiten. Salah satu faktor yang mempengaruhi harga saham adalah kemampuan perusahaan membayar deviden, besarnya deviden ini akan mempengaruhi harga sahamnya. Apabila deviden yang dibayar tinggi, maka harga saham cenderung tinggi, sehingga nilai perusahaan juga tinggi sebaliknya bila deviden yang dibayarkan kecil, maka harga saham perusahaan tersebut juga rendah, sehingga nilai perusahaan rendah (Martono dan Harjito, 2010).

\subsection{Hubungan Kinerja Keuangan dan Harga Saham}

Harga saham merupakan salah satu indikator keberhasilan pengelolaan perusahaan, jika harga saham suatu perusahaan selalu mengalami kenaikan, maka investor atau calon investor menilai bahwa peruasahaan berhasil dalam mengelola usahanya. Kepercayaan investor atau calon investor sangat bermanfaat bagi emiten, karena semakin banyak orang yang percaya terhadap emiten maka keinginan untuk berinvestasi pada emiten semakin kuat. Semakin banyak permintaan terhadap saham suatu emiten maka dapat menaikkan harga saham tersebut. Jika harga saham yang tinggi dapat dipertahankan maka kepercayaan investor atau calon investor terhadap emiten juga semakin tinggi dan hal ini dapat menaikkan nilai emiten. Sebaliknya, jika harga saham mengalami penurunan terusmenerus berarti dapat menurunkan nilai emiten dimata investor atau calon investor (Zuliarni, 2012). Investor sebelum berinvestasi terlebih dahulu akan melihat laporan keuangan perusahaan yang bersangkutan. Kondisi keuangan perusahaan tercermin dalam rasio-rasio keuangan diantaranya rasio likuiditas, profitabilitas, solvabilitas, aktivitas serta rasio pasar modal. Apabila kondisi keuangan perusahaan yang bersangkutan yang 
tercermin dalam rasio-rasio keuangan itu baik, maka investor akan mendapatkan return yang tinggi karena perusahaan memperoleh laba.

\subsection{Kerangka Konseptual Penelitian}

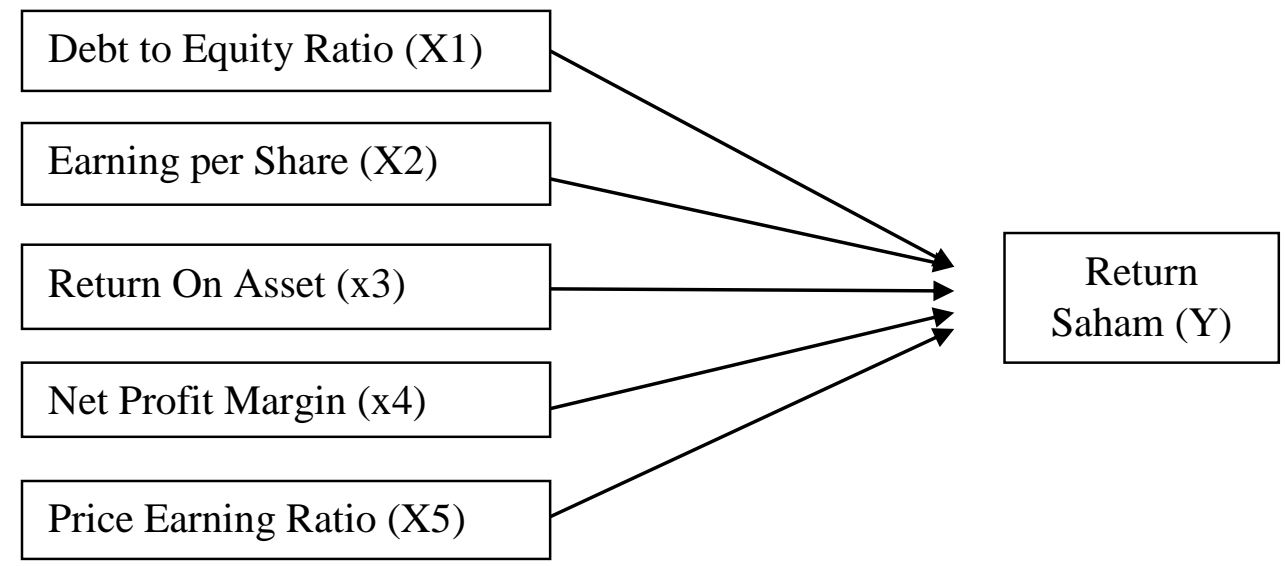

Gambar 2.1 Kerangka Konseptual Pemikiran

\subsection{Hipotesis}

Berdasarkan rumusan masalah dan tujuan yang ingin dicapai dalam penelitan serta tinjauan pustaka yang telah diuraikan sebelumnya, maka hipotesis yang dapat diajukan dalam penelitian ini adalah:

1. H1 :DER berpengaruh positif terhadap harga sahampada perusahaan Mining and mining service yang terdaftar di BEI periode 2012-2016.

2. H2 :EPS berpengaruh positif terhadap harga sahampada perusahaan mining and mining service yang terdaftar di BEI periode 2012-2016.

3. H3 :ROA berpengaruh positif terhadap harga sahampada perusahaan Mining and mining service yang terdaftar di BEI periode 2012-2016.

4. H4 :NPM berpengaruh positif terhadap harga sahampada perusahaan mining and mining service yang terdaftar di BEI periode 2012-2016.

5. H5 : PER berpengaruh positif terhadap harga sahampada perusahaan mining and mining service yang terdaftar di BEI periode 2012-2016.

6. H6 : DER,EPS,ROA,NPM dan PER secara bersama-sama berpengaruh signifikan terhadap Return Saham.

\section{Metodologi Penelitian}

Jenis penelitian ini di adalah penelitian Deskriptif Kuantitatif. Penelitian ini menguji pengaruh antara variabel $\mathrm{X}$ yaitu rasio fundamental dan variabel $\mathrm{Y}$ yaitu harga saham. Penelitian dilakukan pada suatu obyek didalam periode tertentu dimana data yang diambil adalah laporan keuangan perusahaan tambang yang terdaftar di Bursa Efek Indonesia. Populasi objek penelitian yang digunakan dalam penelitian ini adalah perusahaan mining dan mining service yang terdaftar di Bursa Efek Indonesia periode 2012-2016 yang terdiri dari 23 perusahaan yaitu : (1)PT.ADARO Tbk, (2)PT.Atlas Resources Tbk, (3) PT. Bara Jaya International Tbk, (4) PT. Borneo Lambung Energy dan Metal Tbk, (5) PT. Berau Coal Energy Tbk, (6) Baramulti Sukses Sarana Tbk, (7) Bumi Resources Tbk, (8) 
Bayan Resources Tbk, (9) Darma Henwa Tbk, (10) Delta Dunia Makmur Tbk, (11)Golden Energy Mines Tbk,(12) Garda Tujuh Buana Tbk, (13)Harum Energy Tbk, (14)Indo Tambang Raya Megah Tbk, (15)Resources Alam Indonesia Tbk, (16) Mitrabara Adiperdana Tbk,(17) Samindo Resuorces Tbk, (18)Perdana Karya Perkasa Tbk, (19)Tambang Batuabara Bukit Asam Tbk, (20) Potrsea Tbk,(21)Golden Eagle Energy Tbk,(22) Permata Prima Sakti Tbk,(23) Toba Bara Sejahtera Tbk.

Sampel adalah sebagian dari elemen-elemen populasi, yang mempunyai ciri dan karakteristik yang sama dengan populasi (Indriantoro, 2002). Sedangkan pengambilan sampel adalah proses memilih sejumlah elemen secukupnya dari populasi, sehingga terhadap sampel dan pemahaman tentang sifat atau karakteristiknya akan dapat membuat kita menggeneralisasikan sifat atau karakteristik pada elemen populasi. Metode pengambilan sampel pada penelitian ini adalah sampling jenuh yaitu tehnik penentuan sampel bila semua anggota populasi digunakan sebagai sampel (Sugiyono, 2007). Sampel penelitian ini diambil dari semua perusahaan mining dan mining service yang terdaftar di BEI selama periode 2012-2016 dan meyampaikan data laporan keuangan lengkap. Jumlah sampel yang memenuhi kriteria dari 23 populasi adalah sejumlah 20 perusahaan yaitu:(1)PT.ADARO Tbk, (2)PT.Atlas Resources Tbk, (3) PT. Bara Jaya International Tbk, (4) PT. Berau Coal Energy Tbk, (5) Bumi Resources Tbk, (6) Bayan Resources Tbk, (7) Darma Henwa Tbk, (8) Delta Dunia Makmur Tbk, (9)Golden Energy Mines Tbk,(10) Garda Tujuh Buana Tbk, (11)Harum Energy Tbk, (12)Indo Tambang Raya Megah Tbk, (13)Resources Alam Indonesia Tbk, (14) Mitrabara Adiperdana Tbk,(15) Samindo Resuorces Tbk, (16)Perdana Karya Perkasa Tbk, (17)Tambang Batuabara Bukit Asam Tbk, (18) Potrsea Tbk,(19)Golden Eagle Energy Tbk,(20) Toba Bara Sejahtera Tbk.

Variabel independen dalam penelitian ini adalah Debt to Equity Ratio (DER), Earning Per Share (EPS), Return on Asset (ROA), Net Profit Margin (NPM) dan Price Earning Ratio (PER), sedangkan variabel dependen dalam penelitian ini adalah return saham (RS).

\section{Variabel Independen}

1. Debt To Equity Ratio (DER) adalah menunjukkan struktur permodalan suatu perusahaan, merupakan perbandingan antara total hutang dan ekuitas yang digunakan sebagai sumber dana perusahaan. (Brigham dan Houston,2014)

$$
\text { DER }=\frac{\text { Total HUtang }}{\text { Total } \text { Asset }}
$$

2. Earning Per Share (EPS), adalah rasio yang mengukur berapa besar laba bersih yang dihasilkan perusahaan untuk setiap lembar saham yang beredar.(Sutrisno,2000)

EPS $=\frac{\text { Earning After } \text { Tax }}{\text { Jumlah Lembar Saham }}$

3. Return On Asset (ROA) adalah merupakan rasio yang diukur dengan membandingkan laba bersih setelah pajak dengan Total Asset (Brigham dan Houston, 2014)

ROA $=\frac{\text { Laba } B \text { ersih }}{\text { Total } \text { Asset }}$ 
4. Net Profit Margin (NPM) adalah merupakan rasio untuk mengukur seberap besar laba bersih yang dapat diperoleh dari setiap rupiah penjuaan perusahaan. Disamping itu rasio ini juga bermanfaat untuk mengukur tingkat efisiensi total pengeluaran biaya-biaya, maka semakin besar tingkat keuntungan yang diperoleh perusahaan tersebut. (Bastian dan Suhardjono, 2006)

$\mathrm{NPM}=\frac{\text { Laba Bersih Setelah Pajak }}{\text { Penjualan Bersih }}$

5. Price Earning Ration (PER) adalah merupakan ukuran untuk menentukan bagaimana pasar memberi nilai atau harga pada saham perusahaan. Keinginan investor melakukan analisis saham melalui rasio-rasio keuangan seperti PER dikarenakan adanya keinginan investor atau calaon investor akan hasil (return) yang layak dari suatu investasi saham. (Sawir,2009).

PER $=\frac{\text { Harga per Saham }}{\text { Laba PerSaham }}$

\section{Variabel Dependen}

Variabel Dependen dalam penelitian ini adalah return saham. Dalam hal ini yang akan digunakan adalah return saham satu periode kedepan sehingga perhitungan return saham merupakan hasil bagi antara selisih harga saham satu periode tahun depan dengan harga saham periode saat ini dibagi harga saham periode saat ini dengan rumus:

$$
\text { Return Saham }=\frac{R t+1-R t}{R t}
$$

Data yang dipakai dalam penelitian ini adalah data sekunder, yaitu data laporan keuangan yang ada di Bursa Efek Indonesia. Metode pengumpulan data yang digunakan adalah metode dokumentasi yaitu dengan cara mencatat data di dapat dalam Annual Report dan laporan keuangan didapat dari IDX. Sedangkan data yang digunakan di dalam rasio profitabilitas, rasio saham, dan harga saham yang di dapat dari data laporan keuangan tahun 2012-2016.

Teknik Analisis Data yang digunakan adalah sebagai berikut:

3.6.1.Uji Asumsi Klasik

a. Uji Multikolinearitas

Jika nilai Variance Inflation Factor (VIF) tidak lebih dari 10 dan nilai Tolerance (TOL) tidak kurang dari 0,1, maka model dapat dikatakan terbebas dari multikolineritas VIF = $1 /$ Tolerance, jika VIF $=10$ maka Tolerance $=1 / 10=0,1$. Semakin tinggi VIF maka semakin rendah Tolerance.

b. Uji Heteroskedastisitas

Deteksi adanya heteroskedastisitas yaitu dengan melihat ada tidaknya pola tertentu pada grafik; dimana sumbu $\mathrm{X}$ adalah $\mathrm{Y}$ yang telah diprediksi dan sumbu $\mathrm{X}$ adalah residual dari (Y prediksi-Y sebelumnya) yang telah di studentized.

c. Uji Autokorelasi

Uji autokorelasi digunakan untuk mengetahui korelasi antar anggota serangkaian data observasi baik data time series maupun cross section. Menurut Santoso (2009:219), 
secara umum untuk menentukan autokorelasi bisa diambil patokan sebagai berikut: Angka D-W di bawah -2 berarti ada autokorelasi positif. Angka D-W di antara -2 sampai +2 berarti tidak ada autokorelasi. Angka D-W di atas +2 berarti ada autokorelasi negatif.

\section{d. Uji Normalitas}

Uji normalitas dalam penelitian ini dapat dilakukan dengan pendekatan grafik Uji normalitas menguji apakah dalam sebuah model regresi, baik variabel dependen maupun variabel independen atau keduanya mempunyai distribusi normal atau tidak.

Model ini digunakan karena penelitian ini mengemukakan variabel bebas lebih dari satu, maka analisis ini digunakan untuk mengetahui pengaruh antara variabel bebas terhadap variabel terikat. Persamaan Regresi Linier Berganda adalah sebagai berikut :

$$
\mathrm{Y}=\alpha+\beta 1 \mathrm{X} 1+\beta 2 \mathrm{X} 2+\beta 3 \mathrm{X} 3+\beta 4 \mathrm{X} 4+\beta 5 \mathrm{X} 5+\beta 6 \mathrm{X} 6+\mathrm{e}
$$

Keterangan: $\mathrm{Y}=$ Return Saham, $\alpha=$ Konstanta, X1-X6 = Koefisien Regresi masingmasing variabel bebas, = Return On Asset, EPS = Earning Per Share, PER = Price Earning Ratio, e = error term (Sutrisno Hadi, 2004).

\subsubsection{Koefisien Determinasi (R Square)}

Semakin besar $\mathrm{R}^{2}$ berarti semakin tepat persamaan perkiraan regresi linear tersebut dipakai sebagai alat prediksi, karena variasi perubahan variabel terikat dapat dijelaskan oleh perubahan variabel bebas. Apabila nilai R2 semakin dekat dengan satu, maka perhitungan yang dilakukan sudah dianggap cukup kuat dalam menjelaskan variabel bebas dengan variabel terikat.

\subsubsection{Pengujian Hipotesis}

1. Uji F

Uji F digunakan untuk menguji Untuk menguji kelayakan model yang dihasilkan dengan menggunakan $\alpha$ sebesar 5\% . Adapun kriteria pengujian sebagai berikut: 1) Jika tingkat signifikan $>0.05$, maka model yang digunakan dalam penelitian tidak layak dan tidak dapat dipergunakan analisis berikutnya; 2) Jika tingkat signifikan $<0.05$, maka model yang digunakan dalam penelitian layak dan dapat dipergunakan analisis berikutnya.

\section{Uji t}

Uji hipotesis yang kedua adalah uji t yaitu menguji koefisien regresi secara parsial untuk mengetahui apakah masing-masing variabel bebas tingkat return on asset, earning per share dan price earning ratio mempunyai pengaruh terhadap variabel dependen yaitu perubahan harga saham. Prosedur pengujian yang digunakan, sebagai berikut : 1) Jika nilai signifikansi Uji t > 0.05, maka $\mathrm{H} 0$ diterima dan $\mathrm{H} 1$ ditolak, yang berarti variabel bebas yang terdiri dari return on asset, earning per share dan price earning ratio secara parsial tidak berpengaruh signifikan terhadap harga saham, 2) Jika nilai signifikansi Uji t $<0.05$, maka H0 ditolak dan H1 diterima, yang berarti variabel bebas yang terdiri dari return on asset, earning per share dan price earning ratio secara parsial berpengaruh signifikan terhadap harga saham 


\section{Hasil dan Pembahasan}

\subsection{Uji Asumsi Klasik}

a. Uji Multikolinearitas

Untuk mendeteksi apakah model regresi kita mengalami multikolinieritas, dapat diperiksa menggunakan VIF. VIF merupakan singkatan dari Variance Inflation Factor. Nilai VIF > 10 berarti telah terjadi multikolinieritas yang serius di dalam model regresi kita (Gujarati, 1991). Suatu model regresi dikatakan bebas dari multikolinearitas jika nilai Tolerance mendekati angka 1 (Santoso, 2017). Nilai VIF pada output regresi terdapat pada tabel Coefficients. Berikut tabel yang berisi ringkasan nilai VIF dan Tolerance yang diambil dari output hasil regresi.

\begin{tabular}{|l|c|c|}
\hline Variabel Bebas & Tolerance & VIF \\
\hline DER & 0,840 & 1,190 \\
\hline EPS & 0,722 & 1,386 \\
\hline ROA & 0,572 & 1,748 \\
\hline NPM & 0,703 & 1,423 \\
\hline PER & 0,979 & 1,021 \\
\hline
\end{tabular}

Berdasarkan tabel di atas, seluruh nilai Tolerance pada variabel bebas tidak ada yang > 1, sedangkan nilai VIF-nya tidak > 10. Dengan demikian dapat dikatakan bahwa model regresi terbebas dari multikolineritas.

b. Uji Uji Heteroskedastisitas

Untuk mendeteksi ada tidaknya heteroskedastisitas dapat dilakukan dengan melihat ada tidaknya pola tertentu pada grafik plot (scatter plot) yang diperoleh melalui output perhitungan regresi. Jika gambar tersebar tidak merata dan tidak membentuk suatu pola berarti model regresi bebas heteroskedastisitas.

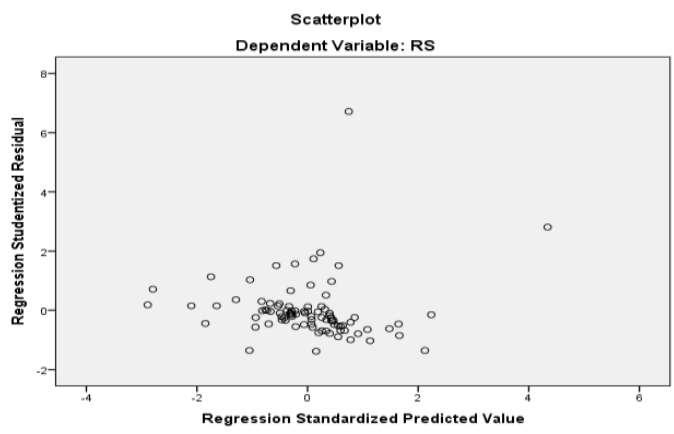

Gambar Scatter Plot di atas menunjukkan bahwa gambar titik-titik tersebar merata dan tidak membentuk suatu pola tertentu misalnya pola naik atau pola turun. Dengan demikian dapat disimpulkan bahwa model regresi tidak mengalami masalah heterokedastisitas dan memenuhi asumsi homokedastisitas.

\section{c. Uji Autokorelasi}

Berdasakan hasil regresi didapati nilai Durbin-Watson (DW) adalah 2,240 yang terdapat pada tabel Model Summary, sedangkan berdasarkan tabel statistik Durbin-Watson dengan nilai probabilita 0,05 , jumlah $\mathrm{n}$ sebanyak 90 , dan jumlah $\mathrm{k}$ sebanyak 6 , didapati 
nilai $d l=1,5181$ serta nilai $d u=1,8014$. Dengan angka yang demikian maka pengujian autokorelasi mencapai kriteria $d u(1,5181)<\mathrm{DW}(1,730)<4-d u(4-1,8014)$ sehingga dapat disimpulkan model regresi tidak mengalami masalah autokorelasi.

d. Uji Normalitas

Pengujian ini menggunakan pendekatan grafik Normal P-P of Regresion Standardized Residual yang didapat dari output perhitungan regresi. Dasar pengambilan keputusan adalah jika data menyebar disekitar garis diagonal dan mengikuti garis diagonal, maka memenuhi asumsi normalitas. Berikut ini gambar grafik Normal P-P of Regresion Standardized Residual.

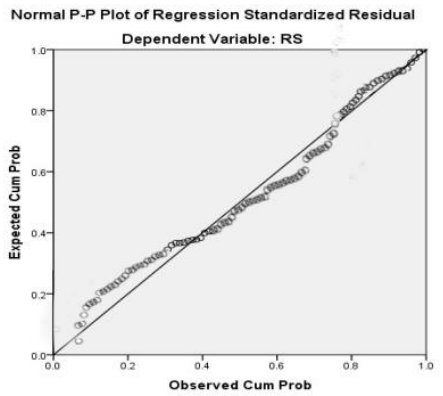

Berdasarkan gambar di atas terlihat data menyebar di sekitar garis diagonal dan mengikuti garis diagonal, dengan demikian dapat ditarik kesimpulan bahwa data terdistibusi dengan normal dan memenuhi persyaratan asumsi normalitas.

\subsection{Analisis Regresi Berganda Coefficients $^{\mathrm{a}}$}

\begin{tabular}{|c|c|c|c|c|c|c|c|c|}
\hline \multirow[b]{2}{*}{ Mod } & & \multicolumn{2}{|c|}{$\begin{array}{l}\text { Unstandardized } \\
\text { Coefficients }\end{array}$} & \multirow{2}{*}{$\begin{array}{c}\text { Standardized } \\
\text { Coefficients } \\
\text { Beta }\end{array}$} & \multirow[b]{2}{*}{$t$} & \multirow[b]{2}{*}{ Sig. } & \multicolumn{2}{|c|}{ Collinearity Statistics } \\
\hline & & $\mathrm{B}$ & Std. Error & & & & Tolerance & VIF \\
\hline 1 & (Constant) & .242 & .143 & & 1.690 & .095 & & \\
\hline & DER & .017 & .021 & .092 & .802 & .425 & .840 & 1.190 \\
\hline & EPS & -.079 & .000 & -.026 & -2.208 & .001 & .722 & 1.386 \\
\hline & ROA & -.022 & .011 & -.281 & -2.028 & .002 & .572 & 1.748 \\
\hline & NPM & .002 & .002 & .137 & 1.101 & .144 & .703 & 1.423 \\
\hline & PER & -.002 & .002 & -.089 & -.847 & .400 & .979 & 1.021 \\
\hline
\end{tabular}

a. Dependent Variable: RS

Berdasarkan tabel di atas maka persamaan model regresi yang didapat adalah sebagai berikut:

$R S=0,242+0,17 D E R-0,79 E P S-0,22 R O A+0,002 N P M-0,002 P E R+0,143$ 


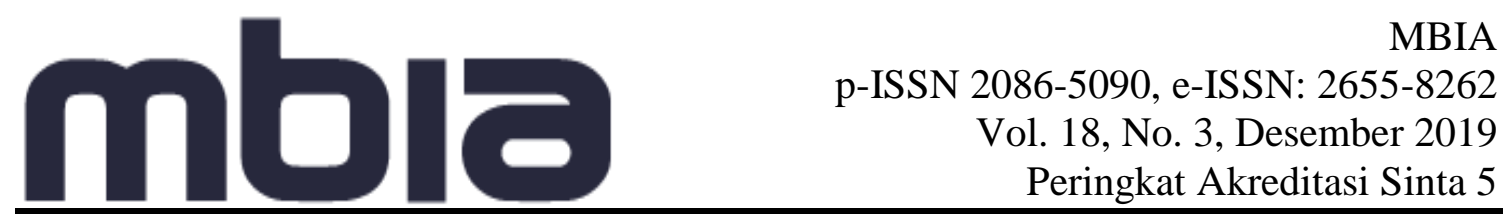

\subsection{Koefisien Determinasi}

\begin{tabular}{|c|c|c|c|c|c|}
\hline \multicolumn{6}{|c|}{ Model Summary } \\
\hline Model & $\mathrm{R}$ & R Square & $\begin{array}{l}\text { Adjusted R } \\
\text { Square }\end{array}$ & $\begin{array}{l}\text { Std. Error of the } \\
\text { Estimate }\end{array}$ & Durbin-Watson \\
\hline & $.633^{\mathrm{a}}$ & .401 & .386 & 1.2132563 & 2.140 \\
\hline
\end{tabular}

a. Predictors: (Constant), PER, EPS, DER, NPM, ROA

b. Dependent Variable: RS

Hasil R Square yang didapat adalah sebesar 0,401 yang artinya bahwa peran variable bebas dalam membentuk variable terikat hanya 40,1 persen, sedangkan sisanya sebesar 59,9 persennya ditentukan oleh variable lain yang berada di luar model.

\subsection{Pengujian Hipotesis}

$\mathrm{Uji} \mathrm{F}$

ANOVA $^{a}$

\begin{tabular}{|ll|r|r|r|r|r|}
\hline Model & & $\begin{array}{c}\text { Sum of } \\
\text { Squares }\end{array}$ & df & Mean Square & F & Sig. \\
\hline 1 & Regression & 9.546 & 6 & 1.591 & 1.185 & $.322^{b}$ \\
& Residual & 123.569 & 92 & 1.343 & & \\
& Total & 133.115 & 98 & & & \\
\hline
\end{tabular}

a. Dependent Variable: RS

b. Predictors: (Constant), PER, EPS, DER, NPM, DPR, ROA

Dengan menetapkan tingkat kesalahan sebesar 0,05, maka didapati hasil uji $\mathrm{F}$ dengan nilai hitung sebesar 1,185 dan nilai signifikansi lebih besar dari 0,05 yaitu sebesar 0,322. Dengan angka seperti itu maka dapat disimpulkan bahwa uji $\mathrm{F}$ memperoleh nilai yang tidak signifikan. Hal ini menunjukkan bahwa secara bersama-sama variable-variabel bebas tidak memiliki pengaruh yang signifikan dalam menentukan variable terikat.

Uji t

DER tidak terbukti mempengaruhi return saham, hal ini terlihat dari nilai uji t sebesar 0,425 lebih besar dari nilai signifikansi sebesar $5 \%$. EPS terbukti mempengaruhi return saham karena nilai uji t sebesar 0,001 lebih kecil dari nilai signifikansi 0,05 dan memiliki hubungan negatif terhadap return saham. ROA juga terbukti mempengaruhi return saham, hal ini terlihat dari nilai uji t sebesar 0,002 lebih kecil dari 0,05 serta juga memiliki hubungan negatif terhadap return saham. Sedangkan variabel NPM tidak terbukti mempengaruhi return saham karena nilai uji t sebesar 0,144 lebih besar dari 0,05. Begitupun juga dengan nilai PER menunjukkan nilai uji t sebesar 0,400 lebih besar dari 0,05 .

\section{Simpulan}

Berdasarkan hasil pengujian yang telah dilakukan dapat ditarik kesimpulan sebagai berikut ;

1. Berdasarkan hasil uji t pada tabel tersebut terlihat bahwa variabel hanya variabel EPS dan ROA yang memiliki pengaruh yang signifikan terhadap Return Saham. 
Variabel EPS dan ROA berpengaruh signifikan dan memiliki hubungan negatif terhadap Return Saham.

2. Hasil uji F menujukan nilai sig. uji $\mathrm{F}$ sebesar 0,322 menunjukan bahwa sebagian besar variabel yang ada dalam penelitian ini tidak terbukti mempengaruhi return saham. Hanya variabel ROA saja yang terbukti mempengaruhi return saham

3. Hasil R Square menunjukkan nilai sebesar 0.401 artinya hanya sebesar 40,1\% return saham dapat dipengaruhi oleh variabel DPR, DER, EPS, ROA, NPM, dan PER sedangkan sisanya sebesar 59,9\% dipengaruhi oleh variabel lain yang tidak ada dalam penelitian ini.

\section{Daftar Pustaka}

Agnes Sawir. (2009). Analisa Kinerja Keuangan dan Perencanaan KeuanganPerusahaan, Jakarta : PT. Gramedia Pustaka Utama.

Bastian, Idra, Suhardjono. (2006). Akuntansi Perbankan, Buku Dua, Edisi Pertama, Salemba Empat, Jakarta.

Belajarinvestasi.my.id. (2017). Pengertian Return Saham.(diakses dari http://belajarinvestasi.my.id/pengertian-return-saham/.8). Juni 2017.

Brigham, Eugene F. dan J. F. Houston.(2014).Manajemen Keuangan. Edisi Kesebelas,Erlangga. Jakarta

Darmadji. T. dan H. M. Fakhrudin.(2001). Pasar Modal Indonesia: Pendekatan Tanya Jawab.Edisi Kedua. Penerbit Salemba Empat. Jakarta

Djarwanto. (2004). Pokok-Pokok Analisis Keuangan. Edisi kedua. BPFE. Yogyakarta.

Gujarati, Damodar. (1991). Ekonometrika Dasar. Penerbit Erlangga. Jakarta

Harahap, S. S. (2007). Analisis Kritis Atas laporan Keuangan. PT. Raja Grafindo Persada. Jakarta.

Husnan, S.(2006). Dasar-Dasar Teori Portofilo dan Analisis Investasi. Edisi Ketiga.Yogyakarta. UPP-AMP YKPN.

Ikatan Akuntan Indonesia. (2005). Standar Akuntansi Keuangan. Penerbit Salemba Empat.Jakarta.

Indriantoro, N. (2002). Metode Penelitian Bisnis Untuk Akuntan \& Manajemen. Penerbit BPFE. Yogyakarta.

Irhan, F. (2011). Manajemen Pengambilan Keputusan. Teori dan Aplikasi. Alfabeta. Bandung

Martono dan A. Harjito. (2010). Manajemen Keuangan. Edisi Kesepuluh. Penerbit Ekonosia.Yogyakarta.

Munawir. (2001). Analisa Laporan Keuangan. Liberty. Yogyakarta

m.tempo.com. (2017) Batubara Tidak Laku, Sudah 11.471 Buruh Kaltim di PHK.(diakses dari $\quad$ https://m.tempo.co/read/news/2015/10/30/092714627/batu-bara-tak-lakusudah-11-471-buruh-kaltim-di-phk)honhowew). 8 Juni 2017

Rendra Yuli Aditya.(2014). Pengaruh Kinerja Keuangan Terhadap Harga Saham Pada Perusahaan Rokok di Bursa Efek Indonesia. Jurnal Ilmu dan Riset Manajemen. STIESIA.Surabaya.

Riyanto. B. (2005). Dasar-dasar Pembelanjaan Perusahaan. Edisi Keempat. Cetakan

Ketujuh.Penerbit BPFE. Yogyakarta.

Santoso, Singgih. (2017). Menguasai Statistik dengan SPSS 24. Elex Media Komputindo. Jakarta. 
Sartono. A.(2005). Manajemen Keuangan. Edisi Ketiga. Penerbit BPFE. Yogyakarta. Siamat. D.(2006). Manajemen Lembaga Keuangan. Edisi Kedua. LPEE-UI. Jakarta.

Sri Zuliarni.(2012). Pengaruh Kinerja Keuangan Terhadap Harga Saham Pada Perusahaan Mining and Mining Service Di Bursa Efek Indonesia(BEI). Jurnal Aplikasi Bisnis Vol.3 No.1 Oktober 2012.

Subana, M dan Sudrajat.(2005), Dasar-Dasar Penelitian Ilmiah, Bandung: Pustaka Setia. Sugiyono.(2007). Metodologi Penelitian Bisnis. Edisi Revisi. Cetakan kesebelas. PenerbitAlfabeta. Bandung.

Sunariyah.(2006). Pengantar Pengetahuan Pasar Modal. Edisi Ketiga. UPP AMP YKPN. Yogyakarta.

Hadi, Sutrisno. (2001). Metode Research, Jilid I. Yogyakarta: Andi

Tendelilin. E. (2005). Analisis Investasi Portofolio. Edisi Pertama. BPFE. Yogyakarta

Wahid AL Hayat.(2014). Pengaruh Rasio Keuangan Terhadap Return Saham (Studi Empiris Pada Perusahaan Sektor Pertambangan Yang Terdaftar Di Bursa Efek Indonesia Periode 2008-2013). Jurusan Akuntansi Fakultas Ekonomi dan Bisnis Universitas Muhammadiyah Surakarta

Weston, J. Fred dan Thomas E. Copeland. 2001. Manajemen Keuangan. Jilid 2. Erlangga. Jakarta

\section{Copyright Disclaimer}

Copyright for this article is retained by the author(s), with first publication rights granted to the journal. 